\title{
The California Irrigation Right
}

$\mathrm{T}$ HE substantive principles of the irrigation laws of the several states and territories are embodied in leading judicial opinions which have established two lines of court decisions by which have been prescribed the two orders of water rights known as the California system and the Colorado system of irrigation law. The irrigation states are each identified with one or the other of the two systems, and their statutory regulations reiterate the theory of antecedent judicial opinions-differing, within the two groups, only in matters pertaining to details of legal procedure and methods of administration. An analysis of irrigation water rights entails, therefore, an historical examination of the judicial decisions which enunciated and established the prevailing principles of property in irrigation waters. Irrigation statutes are chiefly indicative of the popular and legislative recognition of juristic theories, and of the relative efficiency of different state governments in the administration of water rights.

Priority Water Rights Upon the Public Domain.

Upon the organization of the state government of California in 1850, property in water for industrial purposes existed only as an extra-legal right defined by the regulations and customs of the miners who had established themselves upon the public lands. Privileges in the use of water for mining and irrigation which were then enjoyed, represented, ipso jure, only quasi-property rights, since they were founded upon local and informal authority to divert waters for placer mining upon government lands which were not legally and formally open to "occupation and appropriation." The policy of non-interference, on the part of the federal government, inade possible the private appropriation of lands and an expeditious use of adjacent streams which became customary.

A legislative act of April I3, I850, declared the common law of England to be the rule of decision generally in California, when not in conflict with the Constitution of the United States or the 
constitution or laws of the state. ${ }^{I}$ But this act was not clear as to what should be included under the term "laws of the state." The codes of the mining districts were judicially supported and widely recognized and administered, but they had not been acknowledged by statute. Moreover, these codes were clearly in conflict with the common law with regard to water rights on inland streams. The second legislature of California, in I851, approached a definition of the status of the local regulations when justices were authorized to admit proof of "customs, usages, or regulations at the bar or diggings" in cases concerning mining claims, when such customs, etc., were not in conflict with the constitution or laws of the state. But this rule of evidence was not extended to higher courts of original and appellate jurisdiction. ${ }^{2}$ In the Revenue Act of 1854 the legislature implied its acknowledgement of the validity of the diversion and non-riparian appropriation of water by providing for a tax upon "canals, water-races, dams, or other works for mining purposes." During a period of five years the diversion of streams for industrial purposes increased rapidly, and the practice, being unchallenged, assumed the diguity of a right. The order of the rights in the same stream invariably followed the locally accepted doctrine of priority of appropriation, and the practice was informally encouraged by both the federal and state governments. ${ }^{3}$

The question of priority of water rights first reached the California courts in $1853 .{ }^{4}$ This first case is of special interest, not as a precedent, but because of the fact that in charging the jury the

I "The Common Law of England, so far as it is not repugnant to or inconsistent with the Constitution of the United States, or the Constitution or laws of the State of California, shall be the rule of decision in all the Courts of this State." Cal. Stats. 1850, p. 219.

In the Civil Code of 1872 the right to acquire the use of water by appropriation w.s a "useful or beneficial purpose" ( $(1410-1411)$ was established, provided however that the common-law rights of riparian owners be respected $(\$ 1422)$. This proviso was repealed in 1887 with the reservation that rights already vested should not be disturbed. Cal. Stats. 1887, p. 114.

2 Civil Practice Act, April 29, 1851, Cal. Stats. 1851, p. 51.

3 "The Legislature has never directly adopted the local rules and customs-as a body, in whole, or in part-of the respective districts, nor has it authorized the miners to adopt any. Neither has it prohibited their adoption in the thousand instances where they have been established and enforced. By implication, it has recognized them of binding force." Yale, Mining Claims and Water Rights, p. 59.

4 Eddy v. Simpson (1853), 3 Cal. 249, 58 Am. Dec. 408. Suit was brought in the district court to recover damages for interference with an alleged water right claimed by virtue of prior appropriation of the waters of Shady Creek, the water being used for mining purposes. The trial court found for the plaintiff, but was not sustained by the Supreme Court and the cause was remanded for retrial. 
trial judge strongly foreshadowed the doctrine which was to become the general rule of decisions in matters of water rights in the arid districts. The opinion of the judge was, in part as follows:

"As a general principle, the party who first uses the water of a stream, is, by virtue of priority of occupation, entitled to hold the same. If a company or association of miners construct a ditch, to carry water from a running stream for mining or other purposes, and they are the first to use the water, locate and construct the ditch, they are legally entitled to the same as their property, to the extent of the capacity of the ditch to hold and convey water. For, if it appears that there is more water running in the stream than the ditch of the first party can hold and convey, then any other party may rightfully take and use the surplus, and it does not matter whether the excess of water be taken from a point above or below the dam of the first party." 5

A second point of interest in this case appears in the opinion of the Supreme Court in reversing the judgment of Judge Barbour, that is, the conservative attitude of the California judiciary toward precedent and their feeling of uncertainty-almost helplessness-in dealing with new economic conditions. In this opinion, we read the following:

"The rule laid down by the court below, while it is a departure from all the rules governing this description of property, would be impracticable in its application and we think it much safer to adhere to known principles and wellsettled law, so far as they can be made applicable to the novel questions growing out of the peculiar enterprises in which many of the people of this state are embarked." 6

The second case of importance, and that designated as the first of the line of opinions establishing the doctrine of appropriation, was Irwin v. Phillips. ${ }^{7}$ This case involved the rights of a canal owner and appropriator of water for mining purposes, as against a subsequent settler and appropriator upon lands from which the stream had been diverted. Judge Baldwin, counsel for the respondent, argued the case without reference to the common-law doctrine of riparian rights, and made no attempt to apply a modifica-

5 The case was tried March 5,1853 , before $\mathrm{Wm}$. T. Barbour, judge of the Tenth Judicial District of California; and so far as is known, to Judge Barbour belongs the distinction of having formulated the first judicial acknowledgment of the doctrine of appropriation in the United States. Eddy v. Simpson (1853), 3 Cal. 249, 250.

6 The opinion was delivered by Justice Wells, Justice Heydenfeldt concurring. Eddy v. Simpson (1853), 3 Cal. 249, 252.

7 (1855), 5 Cal. 140, 141, 63 Am. Dec. 113. 
tion of that doctrine or to interpolate the laws of custom and necessity within the purport of the common law. He maintained that the policy of the government with respect to the mineral lands of the United States created a necessity for the initiation and application of new principles by the courts. He contended that this policy was sufficiently clear to create a right of individual appropriation, subject to such limitations
"as may be necessary to give effect to two leading principles: First, the most productive working of the mines. Second, the interest, convenience, and profit of the greatest number. But these last principles are subservient to another principle, which is necessary to give effect to these primary principles; and this principle is protection to labor and encouragement of it, which can only be given by allowing to mining claims and appropria- tions a right of property, with its incidents."

The argument of Counsel Baldwin was adopted by the Supreme Court, in an opinion written by Justice Heydenfeldt and concurred in by Justice Murray. The opinion of the court is, in part, as follows:

"Courts are bound to take notice of the political and social condition of the country, which they judicially rule. In this State the largest part of the territory consists of mineral lands, nearly the whole of which are the property of the public. No right or intent of disposition of these lands has been shown either by the United States or the State governments, and with the exception of certain State regulations, very limited in their character, a system has been permitted to grow up by the voluntary action and assent of the population, whose free and unrestrained occupation of the mineral region has been tacitly assented to by the one government, and heartily encouraged by the expressed legislative policy of the other. If there are, as must be admitted, many things connected with this system, which are crude and undigested and subject to fluctuation and dispute, there are still some which a universal sense of necessity and propriety has so firmly fixed as that they have come to be looked upon as having the force and effect of res judicata. Among these the most important are the 1 ights of miners to be protected in the possession of their selected localities, and the rights of those who, by prior appropriation, have taken the waters from their natural beds, and by costly artificial works have conducted them for miles over mountains and ravines, to supply the necessities of gold diggers, and without which the most important interests of the mineral region would remain without development. So fully recognized have become these rights, that without any specific legislation conferring, or confirming them, they are alluded to and spoken of in various acts of the Legislature in the same 
manner as if they were rights which had been vested by the most distinct expression of the will of the law makers; as for instance, in the Revenue Act, 'canals and water-races' are declared to be property subject to taxation, and this when there'was none other in the State than such as were devoted to the use of mining. " This simply goes to prove what is the purpose of the argument, that however much the policy of the State, as indicated by her legislation, has conferred the privilege to work the mines, it has equally conferred the right to divert the streams from their natural channels, and as these two rights stand upon an equal footing, when they conflict, they must be decided by the fact of priority, upon the maxim of equity, qui prior est in tempore potior est in jure..

"The miner who selects a piece of ground to work, must take it as he finds it, subject to prior rights, which have an equal equity, on account of an equal recognition from the sovereign power. If it is upon a stream the waters of which have not been taken from their bed, they cannot be taken to his prejudice; but if they have been already diverted, and for as high and legitimate a purpose as the one he seeks to accomplish, he has no right to complain, no right to interfere with the prior occupation of his neighbor, and must abide the disadvantages of his own selection."

In this decision and opinion, a well defined position was taken in opposition to the maintenance of property rights in natural waters as known to the common law, though the common law was nominally the rule of decision in California prior to that time. The innovation was frankly based upon facts of physical conditions and necessities of social and economic relations resulting therefrom. It is noteworthy that this opinion unfolds the salient principles of the present-day irrigation water right, as confirmed by the doctrine of priority of appropriation and beneficial use. The principles of Baldwin and Heydenfeldt were not accepted, however, without contest. For thirteen years the judicial precedent stood without legislative sanction, and certain vested interests and juristic conservatives waged a stubborn opposition in the courts of California until I862. ${ }^{10}$ The doctrine of appropriation was not fully supported

${ }^{8}$ Section 2, Art. IX, of the same act, provides for the assessment of the property of companies and associations. Among objects mentioned are "dam or dams, canal or canals, or other works for mining purposes."

${ }^{9}$ Irwin v. Phillips (1855), 5 Cal. 140, 146, 63 Am. Dec. 113.

10 "There are two antagonistic interests in the state, each endeavoring to control the legislature, and to shape the legislation entirely in its own behalf, to the complete exclusion of the other. These are the riparian proprietors, who assert thcir common-law rights, and would exclude all other classes from the participation in the waters of the streams however abund- 
by the United States Supreme Court until $1874^{11}$ Although this court did not even then pass directly upon the question, it became clear that water-rights controversies were to be decided in accord with the customs, laws, and decisions prevailing in the respective states and territories. This policy was confirmed by a decision in I890, in which the court said: "The local custom is set forth ... to have consisted in the recognition and acknowledgment of 'the right to locate water rights, and to divert, appropriate and use the waters of flowing streams for purposes of irrigation, when such location, diversion and use does not conflict or interfere with rights vested and accrued prior thereto.' Thus, under the laws of Congress and the Territory (Dakota), and under the applicable custom, priority of possession gave priority of right."12

The final word in the recognition of the frontier doctrine of appropriation and of the authority of a state in its application to the use of irrigation waters was pronounced in 1907 by the United States Supreme Court, in Kansas v. Colorado. ${ }^{13}$ The court asserted that

"each State has full jurisdiction over the lands within its borders, including the beds of streams and other waters. It may determine for itself whether the common-law rule in respect to riparian rights or that doctrine which obtains in the arid regions of the West of the appropriation of waters for the purposes of irrigation shall control. Congress cannot enforce either rule upon any State."

It should be borne in mind, in connection with the evolution of the arid-land water right, that up to 1856 , questions of the use of water in California concerned only the mining industry; and the locus of water rights, with few exceptions, was confined to the mineral lands of the public domain not legally open to occupation and settlement. The newly developed property right in natural

ant; and the communities of land owners away from the banks of the streams who deny any rights of the riparian proprietors, and claim a free, unrestricted access to and appropriation of all material streams, limited only by the extent of their own needs." Black's Pomeroy on Waters, p. 349 . See also Crandall v. Woods (1857), 8 Cal. 136; McDonald v. Bear River Co. (1859), 13 Cal. 220; Logan v. Driscoll (1862), 19 Cal. 623.

11 Atchison v. Peterson (1872), 1 Mont. 561 ; Basey v. Gallagher (1874), 87 U. S. 670,22 L. Ed. 452 ; Jennison v. Kirk (1878), 98 U. S. 453, 25 L.' Ed. 240.

12 Sturr v. Beck (1890), 133 U. S. 541, 33 L. Ed. 761, 10 Sup. Ct. Rep. 350.

13 Kansas v. Colorado (1906), 206 U. S. 46, 93, 51 L. Ed. 956, 27 Sup.

Ct. Rep. 655 . 
waters was popularly assumed to be the special prerogative of miners, which distinction the legislature sought to establish by statute in 1854 .

\section{Riparian Rights Upon Private Estates.}

The federal act of July $26,1866,{ }^{14}$ together with the judicial decisions noted above, clearly established the right to appropriate the use of water flowing upon the public lands in the state of California. The doctrine of priority of appropriation for beneficial use, irrespective of the common law, has since been universally held and understood to fix the order of water rights upon the public domain and the custom preceded the right by twenty years. The question of the application of these principles upon private estates became pertinent upon the granting of private title in California lands under the federal law.

The determination of the respective water rights incident to and subsequent to public and private estates, necessarily entails a declaration as to the precise source of the right to use the waters of natural streams; and upon this point has centered the chief conflict over irrigation rights in the United States. A California decision of 1857 attempted to sustain the common-law riparian right upon private estates against all priority rights except such as were established while the land was still a part of the public domain. ${ }^{15}$ Because of the indirect bearing of this case and the uncertain nature of the opinion the decision has not been recognized as a ruling precedent. ${ }^{16}$ In spite of scattering implications to the

14 The Congressional act of July 26, 1866 declared that mineral lands of the United States were free and open to exploration and occupation, subject to such regulations as might be prescribed by law and the local customs or rules of the inhabitants of the several districts, as far as the same were not in conflict with the laws of the United States. The act further provided that water rights established by priority of possession should be maintained and protected, and the right of way for canals and ditches for the purpose of diverting water for mining, agricultural, or mechanical use was acknowledged and confirmed. Supplementary acts of July 9, 1870 and May 10, 1872, made all subsequently issued land patents subject to previously recognized water rights.

15 Crandall v: Woods (1857), 8 Cal. 136. In this case it was advanced that the rule established in Irwin v. Phillips was by no means exclusive of riparian rights, but that such rights attach to the land through which a stream flows, in favor of settlers thereon, as against all but appropriations actually made prior to the settlement of the land.

${ }_{18}$ The opinion has been deemed somewhat biased because of the fact that it was uttered by Justice Murray at a time when he was attempting to shape the doctrine of appropriation as a modification of the common-law rule and not to ye recognized as the basis of an independent system. Wiel, Water Rights in the Western States (1st Ed.), p. 33. Moreover, the 
contrary, ${ }^{17}$ the prevalent impression, prior to I886, was that the common-law doctrine of riparian rights had been rejected in toto in California. ${ }^{18}$

In I886, in the case of Lux v. Haggin, the Supreme Court of California established a definite principle as the basis of water rights in that state which remains the rule of decision to the present day. The case involved the right to the use of the waters of Kern River in the San Joaquin Valley, and the plaintiffs invoked the doctrine of riparian rights to relieve them from injury resulting from the appropriation of the waters of the stream for purposes of irrigation. The lower court found neither party to be a riparian owner and decided in favor of the defendant. The plaintiffs, however, alleged riparian rights and appealed to the Supreme Court of the state. The Supreme Court applied the law to the issues as made by the pleadings and left the facts to be determined by a new trial. In an opinion occupying nearly two hundred pages of the California Reports, the plaintiffs were sustained in their alleged supremacy of the riparian right over subsequent appropriations for use, three of the seven members of the court dissenting. ${ }^{19}$ The court maintained that the rule of priority of appropriation was unknown to the common law, ${ }^{20}$ but that, although independent of the common-law doctrine of riparian rights, it was not destructive thereof. Appropriation was sustained as the basis of rights in the use of water upon public lands; but the riparian right of the common law was declared to attach to all land as soon as it becomes private, remaining subject to appropriations made prior to that time, and free from hostile appropriations thereafter. ${ }^{21}$ It was further advanced that riparian rights were to be protected upon constitutional principles, and that their abrogation permitted the

riparian estate under discussion was a mining claim, and the use desired quite foreign to the common law. Only two or three times has a court attempted to use this opinion as a precedent.

17 "We have recognized the right to appropriate where no riparian rights intervene." Conger v. Weaver (1856), 6 Cal. 548. 65 Am. Dec. 528. "Possession, or actual appropriation, must be the test of priority in all claims to the use of water, whenever such claims are not dependent upon the ownership of the land through which the water flows." Kelley v. Natoma Water Co. (1856), 6 Cal. 105.

${ }_{18}$ Pomeroy on Waters, $\S 108$; Wiel, Water Rights in the Western States, p. 33; Lux v. Haggin (1886), 69 Cal. 255, 4 Pac. 919, Dissenting opinion.

${ }^{19} \mathrm{Lux}$ v. Haggin, supra, n. 18.

20 Ibid, pp. 387-389.

21 Ibid, pp. 368, 375, 380. 
taking of property without due process of law and made possible an unwarranted interference by the state with the primary disposal of the federal lands. ${ }^{22}$

Lux v. Haggin clearly established a restricted form of commonlaw riparian rights in California, but the doctrine of appropriation was simultaneously acknowledged and is still recognized--both judicial and statutory law grant the two doctrines concurrent existence as the respective bases of two contemporaneous systems of water rights in that state. In theory, the two systems are of equal importance and command equal consideration by the courts but, as the lands of California passed into private ownership, the common-law principle, although gradually modified, acquired a widened sphere of application, while the field of priority rights has proportionately narrowed.

The bifurcated garment of irrigation jurisprudence evolved

22 Upon the first appeal, Justice Sharpstein contrasted the contending doctrines of riparian rights and appropriation in the following terms: "But it is insisted by respondent's counsel that both the United States and the State have adopted a policy, in respect to water flowing over their lands, which is inconsistent with the doctrine of riparian rights as we construe it. As a result of that policy, it is claimed that a grant of land by either of those governments must be read as if it contained a condition that any one should, thereafter, be at liberty to appropriate so much of the water of any natural stream running over such lands as the grantee had not previously appropriated to some useful purpose other than that which is subserved by flowing naturally over such land. That would constitute a reservation of an interest in the land granted, not for the benefit of the grantor, but for that of any other person who might choose to avail himself of it. If a grant does not contain any such expressed reservation or condition, we ought not to interpolate one unless it is clearly implied, because the general rule is that the owner of property cannot be divested of any interest in it by the simple prior appropriation of that interest in it by some one else. Both, the State and the United States governments have granted to private persons and corporations large tracts of land which have remained unoccupied and in their virgin state for many years afterwards. It probably never occurred to any one that the owners, by neglecting to appropriate the grasses and trees naturally growing on such lands to some useful purpose, left them open and subject to a rightful appropriation by some one else. And yet we have the same authority for holding that a simple grant of land conveys a right to have the water flowing over it continue so to flow, as we have for holding that it conveys a right to the trees and grasses growing on it, or to the soll itself. The principle that he who first appropriates property to a useful purpose is best entitled to it, applies only to cases in which none of the parties has a grant, actual or presumptive."

The opinion in Lux v. Haggin was concurred in by Justices McKinstry, McKee, Sharpstein, and Thornton. Justices Morrison, Ross, and Myrick dissented-affirming that the adoption of the common law, by act of legislature, April 13, 1850, "was not intended to and did not establish a rule of decision as to the right of appropriation of water for irrigation," and that, if applied, the common law must be interpreted in the light of conditions prevailing in the country in which the application is made. Ibid, p. 440. 
from the opinion of a divided court in Lux v. Haggin is known as the California system and has been essentially adopted in the states of California, Oregon, ${ }^{23}$, Washington, ${ }^{2+}$ Montana, ${ }^{25}$ North Dakota, ${ }^{26}$ Nebraska, ${ }^{27}$ Texas, ${ }^{28}$ Kansas, ${ }^{29}$ and South Dakota. ${ }^{30}$

The law, as established by the ruling decision, has since been supplemented by precision as to the time of the inception of water rights and the manner in which they may divest. Rights of riparian proprietors are held to attach simultaneously with the acquisition of private title in the land, and will thereafter be protected, in a reasonable and proportionate use against subsequent appropriation. ${ }^{31}$ Water rights, having been acquired by nonriparian proprietors, may be divested by grant from such proprietors, or by operation of law, through prescription, adverse user, or condemnation. $^{32}$ In controversion of the common law, riparian rights have also been made subject to valuation apart from the land $^{33}$ and to condemnation under eminent domain, and to extinction by prescription and adverse use, and to accomplish this, statutes and court decisions in states of the California system have

23 Carson v. Gentner (1898), 33 Ore. 512, 52 Pac. 506.

24 Benton v. Johncox (1897), 17 Wash. 277, 49 Pac. 495; Sander v. Wilson (1904), 34 Wash. 659, 76 'Pac. 280.

${ }_{25}$ Smith v. Denniff (1900), 24 Mont. 20, 60 Pac. 398.

26 Bigelow v. Draper (1896), 6 N. Dak. 152, 69 N. W. 570.

27 Crawford Co. v. Hathaway (1903), 67 Neb. 325,93 N. W. 781.

28 McGhee, etc. Co. v. Hudson (1893), 85 Tex. 587, 22 S. W. 398; Mud Creek etc. Co. v. Vivian (1889), 74 Tex. 170, 11 S. W. 1078; Watkins Land Co. v. Clements (1905), 98 Tex. 578, 86 S. W. 733.

29 Clark v. Allaman (1905), 71 Kan. 206, 80 Pac. 571.

${ }^{30}$ Lone Tree Ditch Co. v. Cyclone Ditch Co. (1902), is S. Dak. 519, 91 N. W. 352. The riparian right was previously affirmed in Dakota Territory by the United States Supreme Court in Sturr v. Beck (1890), 133 U. S. 541, 33 L. Ed. 761, 10 Sup. Ct. Rep. 350.

31 That section of the California civil code ( $\$ 1422$ ) which sustained the common law as the general rule of decisions was repealed in 1887-the year following the decision in Lux v. Haggin, Cal. Stats. 1887, p. 144. The repeal is held, however, not to affect the rights of riparian proprietors since the leading case was decided independently of the code provision.

"Recent cases in California show a decided tendency to cease citing the older cases on appropriation, assuming the doctrines there laid down as established and familiar law. This indicates that in California the law of appropriation has taken its place as a complete system, past the formative period in which the system may be said to remain in younger states." Wiel, Water Rights in Western States, op. cit., p. 36. Benton v. Johncox (1897), 17 Wash. 277; Sturr v. Beck (1888), 6 Dak. 71; Sturr v. Beck (1889), 133 U. S. 541 .

32 Mills, Irrigation Manual, p. 30, and cases there cited.

${ }^{3}$ San Joaquin \& Kings River Co. v. Stanislaus County (1914), 191 Fed. 898; San Joaquin \& Kings River Co. v. Stanislaus County (1914), 233 U. S. 454 . 
declared the use of waters of natural streams for beneficial purposes to be a public use. ${ }^{3 *}$

The constitution of California recites that "the use of all water now appropriated, or that may hereafter be appropriated, for sale, rental or distribution, is hereby declared to be a public use, and subject to the regulation and control of the state, in the manner to be prescribed by law." ${ }^{34 a}$ A recent decision of the Supreme Court of California has finally interpreted the legal significance of this "public use." "Under the law of this state, . . . the water right which a person gains by diversion from a stream for a beneficial use is a private right. The same is true as to water rights in streams upon the public domain in California. The title and ownership is private and the only interest of the public is that of beneficiaries of the use or trust. The property does not become impressed with a public use or trust until after the owner has first acquired it and then dedicated it to the use. The acts of acquisition and dedication are distinct." 35

An act of April 8, I9II, amended the Civil Code so as to declare "all water or the use of water, within the State" to be "the property of the people of the State of California." The interpretation, by the Supreme Court, of this amendment to the Code, seems to strip it of any probable importance in relation to water rights within the state. It is not retroactive. The only effect which it may have is to dedicate to general public use any riparian rights which the state, at the time it was enacted, may still have retained by virtue of its ownership of lands bordering on the streams, which it would, in such cases, have in common with owners of other abutting land. All previously established rights, whether riparian, or prescriptive, remain unaffected. ${ }^{36}$

The Supreme Court of California in I9I5 reaffirmed the legal superiority of the riparian water right in that state in such positive terms as to leave no room for doubt concerning the juristic policy

34a Cal. Const. Art. XIV, § 1.

${ }^{34}$ Lux v. Haggin, supra, n. 18; Cal. Pastoral \& Agricultural Co. v. Madera Canal \& Irri. Co. (1914), 167 Cal. 78, 138 Pac. 718; Border v. Trespalacios R. \& I. Co. (Texas, 1904), 82 S. W. 461, 98 Tex. 494, 86 S. W. 11, 107 Am. St. Rep. 640; Bullderick v. Hermsmeyer (1905), 32 Mont. 541, 81 Pac. 334.

35 Thayer v. California Development Co. (1913), 164 Cal. 117, 128 Pac. 21 .

36 Cal. Civ. Code, § 410; Palmer v. Railroad Commission (1914), 167 Cal. 163, 175, 138 Pac. 997. 
underlying the present California system of irrigation law. Reviewing the judicial decisions since Lux v. Haggin, the court said:

"These decisions show that while an appropriation or diversion made upon lands of the United States gives the appropriator or diverter a right to the water as against the United States it does so solely because, by the act of Congress of July I6, I866, the United States declared that such diversion, if recognized by local laws, should be effectual to confer upon the diverter the riparian rights in the stream pertaining to the land of the United States abutting thereon, that it gives no right as against other landowners, that it does not take place upon the theory that the water is held by the United States for public use, but because, as proprietor of the land, the United States, by that act, granted a part of its property in its land to such diverter. Also they show that the appropriator under the Code may obtain a similar right as against riparian rights of the state pertaining to any lands which the state may own along the course of the stream; but that this right may be thus acquired, solely because the state in section I4IO of the Civil Code has so declared, and that this declaration binds the state as to its proprietary lands, but does not affect lands of other persons, or water rights pertaining to such other lands, and that, except its riparian rights pertaining to lands which it owns bordering upon non-navigable streams, the state has no right to the waters thereof and, consequently, cannot dispose of any other rights." 37

The supreme courts of Nebraska and Oregon have partial'y removed those states from the effect of the common-law right as it obtains in the other states of the California system. In 1903, the Nebraska court construed the state irrigation law of 1889 as having abrogated the rule of riparian proprietorship in the acquisition of water rights since that time; maintaining, however, that riparian rights which had accrued prior to the enactment of the law should be protected. ${ }^{38}$ In 1908 , the Oregon court placed a similar construction upon the Federal Desert Land Act of 1877; that is, that public lands entered after that date were accepted with the implied understanding that, except as to use for domestic purposes, the first to appropriate and use the water for irrigation should have the superior right. $^{39}$

37 Duckworth v. Watsonville Water \& Light Co. (1915), 170 Cal. 425, 432, 150 Pac. 58.

${ }_{38}$ Crawford Co. v. Hathaway (1903), 67 Neb. 325, 93 N. W. 781.

39 Hough v. Porter (1908), 51 Ore. 318,95 Pac. 732. These rulings have, however, mainly served to enlarge the degree of elasticity or the sphere of judicial discretion in defining water rights. 


\section{Theory of the California Water Right.}

By the treaty of Guadalupe Hidalgo, Feb. 2, I848, the United States succeeded to the Mexican title and became the sole owner of the lands and natural waters of the so-called Mexican Cession, with the exception of certain private estates created by prior grants from the Mexican government which the United States respected.

The theory upon which present water rights rest in this country assumes that, in the absence of statutes, the common law became operative simultaneously with the acquisition of title by the United States. Under a strict interpretation of the common law, the federal government succeeded to a complete riparian proprietorship in its waters when it became sole proprietor in fee simple of the land. These property rights, until transferred to private persons, have been held by the United States exactly as in private ownership, with the exception that they are not taxable. Upon these grounds, it is maintained that the United States, as sole proprietor, had unlimited right to do with the streams upon its land as it chose. It could (I) transfer the land together with the use of the water thereon as an incident thereto, or (2) it could grant each separately, and, furthermore, (3) lawful grants could be expressed, or could be implied by non-interference.

Up to 1866 , the United States acquiesced in the customs and regulations established by the California miners which permitted the separate appropriation of the water. In fact, land and water were customarily appropriated separately, and, by the acts of 1866 and 1870 , such implied grants of separate appropriations were confirmed and future titles were guaranteed when the appropriations were upon government land. It is further held that the government has chosen to transfer a part of its lands, together with incident riparian rights, under the generally accepted meaning of the common law, and that such a transfer is presumed when the water upon the land has not previously been separately granted. ${ }^{40}$

In Lux v. Haggin, the court said:

"Recognizing the United States as the owner of the lands and waters, and as therefore authorized to permit the occupation or diversion of the waters as distinct from the lands, the State courts have treated the prior appropriator of water on

40 Lux v. Haggin, supra, n. 18; Mills, Irrigation Manual, p. 28 and cases there cited; Kinney, Irrigation \& Water Rights (1st Ed.), $\$ \$ 135,148,188$; Wiel, Water Rights in Western States (2d Ed.), p. 49 et seq; Pomeroy and Farnham, passim. 
the public lands of the United States as having a better right than a subsequent appropriator, on the theory that the appropriation was allowed or licensed by the United States. It has never been held that the right to appropriate waters on the public lands of the United States was derived directly from the State of California as the owner of innavigable streams and their beds. And since the act of Congress granting or recognizing a property in the waters actually diverted and usefully applied on the public lands of the United States, such rights have always been claimed to be deraigned by private persons under the act of Congress, from the recognition accorded by the act, or from the acquiescence of the general government in previous appropriations, made with its presumed sanction and approval." 41

Courts of other states, in sustaining the California system have held that, "As the United States ... . owns the waters which are an incident to its lands, it can dispose of them separate from its lands if it chooses," 42 and that "The water in an innavigable stream flowing over the public domain is a part thereof, and the national government may sell or grant the same, or the use thereof, separate from the rest of the estate, under such circumstances as may seem to it proper." 43

The origin of the priority property right in water-a grant from the United States to the appropriator-as recognized by the California system, has frequently been reiterated in judicial opinions. In the language of Justice Baldwin, in Ortman v. Dixon," "We hold the absolute property in such cases to pass by appropriation as it would by grant." Other courts have held the appropriator of water on the public domain to be "a licensee of the general government," and that when such parts of the public lands pass into private ownership they are "burdened by the easement granted by the United States" to the prior appropriator of the water. ${ }^{45}$ It is further asserted that a grant of the separate use of water must issue from the owner of both the land and the water, and "The right acquired by appropriation and user of the water on the public domain is founded in grant from the United States government as the owner of the land and water," 46 and, "under the law of Congress, a grant of the kind of property in question is pre-

${ }^{11}$ Lux v. Haggin (1886), 69 Cal. 255, 338.

42 Cruse v. McCauley (1899), 96 Fed. 369, 374 (Montana).

43 Howell v. Johnson (1898), 89 Fed. 556 (Montana).

44 (1859), 13 Cal. 33.

45 Smith v. Hawkins (1895), 110 Cal. 122, 42 Pac. 453.

46 Smith v. Denniff (1899), 24 Mont. 20, 60 Pac. 398. 
sumed by the act of appropriation." 47 The right of appropriation and user, being deemed a grant from the United States to the appropriator, it is assumed that the grantor had authority to impose conditions and did so by the recognition of prevailing local customs and voluntary regulations which required that the appropriator should make a "beneficial use" of the water diverted. ${ }^{48}$

The Supreme Court of California in I9I2 clearly alleged the prevalence of a theory of the law in that state which should make beneficial use the primal and ultimate sanction of the right to appropriate water for purposes of irrigation:

"It is the well-settled law of this state that one making an appropriation of the waters of a stream acquires no title to the waters, but only a right to their beneficial use, and only to the extent that they are employed for that purpose. His right is not measured by the extent of his appropriation as stated in his notice or by his actual diversion from the stream, but by the extent to which he applies such waters for useful or beneficial purposes. Beyond that, his appropriation or diversion of more than can be applied by him gives him no right to the excess, and this is subject to appropriation by any other person who may use it for similar beneficial purposes."49

We may not conclude, however, that this socially beneficial and universally applauded principle of irrigation water rights is no longer trammeled in California by the skeleton of legal legitimism and exclusive vested rights; for we read in the obiter dicta of the same court, in I9r5:

"It may well be that there is room for an even need for legislation which will require riparian proprietors to exercise their irrigation rights in the use of water within a limited period, or be decreed to have waived those rights. Other similar legislation making for the general good will readily occur to one's mind. But it is not the province of this court to legislate, and it would be abhorrent to justice now to say to an upper riparian proprietor, who has rested in security upon the rights which this court has over and over again declared to be his, that he has lost those rights through no fault or failure of his own, but simply because he has not seen fit to use the waters upon his riparian land." 50

47 Barkley v. Tieleke (1874), 2 Mont. 59.

48 Wiel, Water Rights in Western States (1st Ed.), p. 53; Pomeroy on Waters, \& 32; Kinney, Irrigation \& Water Rights, \& 147.

49 Hufford v. Dye (1912), 162 Cal. 147, 153, 121 Pac. 400.

50 Miller \& Lux v. Enterprise Canal \& Land Co. (1915), 169 Cal. 415, 147 Pac. 567. 
The effective theory of the California water right is mainly the product of what may be called the legitimist school of juristic thought. The California water right owes its legal sanction to that philosophy which grants prevalence to time-established principles because of former recognition and application, proprio vigore, rather than because of fitness to actual and potential economic and social needs. The right is based upon the theory that the common law of England contains, in germ or development, all legal principles essential or beneficial to society. Novel climatic conditions and resulting economic necessities in Califorma have been met by perennial judicial amendment and temporizing reinterpretation of the common-law concepts of property and contract, rather than by positive and constructive measures. Considered in the light of the theory and origin of law, California has established a hybrid practice in the acquisition, use, and transfer of property in water,-a practice in fact unknown to the tenets of the common law, which, nevertheless, is its judiciably determined mater familias. ${ }^{51}$ Finally, the California theory of irrigation water rights assumes that the sovereignty which passed from Mexico to the United States was a common-law property in the lands and the natural waters thereon; consequently, rights in such lands and waters may be granted to private owners within limits established by the common-law conception of property, but beyond which the government, never having owned, has nothing with which to part and cannot confer title. The government may confer, by specific

51 In evidence of the judicial recognition of this fact, such opinions as the following are not infrequent:

"The business of gold mining was not only new to our people, and the cases arising from it new to our Courts, and without judicial or legislative precedent, either in our own country or in that from which we have borrowed our jurisprudence; but there are problems intrinsic in the subject itself that it is almost impossible to settle satisfactorily, even by the application to them of the abstract principles of justice." Justice Burnett, in Bear River Water Co. v. N. Y. Mining Co. (1850), 8 Cal. 327, 332.

"There are many questions of great doubt and difficulty, peculiar to the Pacific coast, to which I have not even alluded." Black's Pomeroy on Riparian Rights, p. 348.

"Various problems in connection with the fair apportionment and economic use of the waters of this state never came within the purview of the common law. They have been of necessity, and must continue to be solved by this court as cases of first impression, and if the rule of decision at common law is found unfitted to the changed conditions in this state, so that its application will work wrong and hardship rather than betterment and good the court will refuse to approve and follow the doctrine." San Joaquin etc. Co. v. Fresno Flume \& Irri. Co. (1910), 158 Cal. 626, 112 Pac. 182. 
or implied terms, property in water for industrial purposes, and the lands, thereby deprived of their riparian rights, will thereafter remain so denuded. But if, at the time of the sale or granting of the land by the government, there shall have been no prior grant of the waters to which it is riparian, the common-law right in such waters passes with the land.

This riparian right is, theoretically, subject to forfeiture by nonuse and prescriptive appropriation, being thus converted, by due process of law, to a property right which is economically sanctioned by beneficial use. In practice, this very desirable transition of impotent common-law rights to fruitful priority usufructs is not now legally expedient, or, indeed, in any considerable degree, possible. The statutory period of prescription in California is five years. At any time during this period a riparian proprietor may enjoin an adverse appropriator upon the theory that such a use is an interference with his freehold which is entitled to restrain lest it ripen into a prescriptive right. The Supreme Court has repeatedly authorized such restraint without requiring a showing of material damages on the part of the riparian owner.

Under this conception of the law, the several states may not themselves define real property within their borders. The proprietors of rights in land or water which was once a part of the public domain derive their property rights from the United States, as land owner under the property concept of the common law, but neither from the state nor the general government as law maker. ${ }^{52}$ The legislative power of the United States would thus appear to be limited to the principles of the common law, and that of the states to the procedure of their courts, and to matters within the police power-the states being subject of course to the constitutional admonition against trespassing on the powers of congress or infringing the guarantees of vested rights.

52 Lux v. Haggin,- supra, n. 18; Cal. Pastoral \& A. Co. v. Madera Canal \& Irri. Co. supra, n. 34; Duckworth v. Watsonville Water \& Light Co. (1915), 170 Cal. 425, 150 Pac. 58; Cal. Civ. Code, \& 1410; Willey v. Decker (1903), 11 Wyo. 496, 73 Pac. 210; White v. Farmers' C. \& R. Co. (1896), 22 Colo. 191, 43 Pac. 1028; Wiel, Water Rights in the Western States, (3rd Ed.), p. 86. 


\section{Summary of Characteristics of the Californta IRRIGATION RIGHT.}

The California system of irrigation jurisprudence may be said to recognize the following principles as fundamental in the law of inland waters:

I. Property rights in the use of inland waters exist by virtue of (a) Mexican grants under the civil law; (b) riparian proprietorship under the common law; (c) prior appropriaation upon the public domain as justified by the customs of the country; (d) conversion of either riparian or priority rights by subsequent appropriation through non-use, declaration of right, adverse use and prescription. The priority right, however, is a derived right, being originally a separate grant of the water-privilege of a riparian property.

2. An appropriation is construed to be a grant from the United States, as proprietor of the public domain, of the use of waters on or adjacent to its lands, and limited only by the total right which the government has in such waters. The right is private property; the use is a "public use."

3. The relation between successive appropriators is that he who is first in time is first in right to the extent of his appropriation and application to beneficial use; and rights in the surplus accrue to subsequent appropriators, each in his turn and to the extent of his use.

4. Between riparian proprietor and appropriator, the relation is that of successive grantees from the same owner. They are independent and priority of title governs; but with the one it is priority of location and occupation of riparian lands, and with the other it is the order of diversion and appropriation of the water. In either case, the surplus over the needs and uses of the grantee, not being included in his grant, remains for the benefit of subsequent riparian proprietors or appropriators.

5. The old common-law limitations as to diminution of quantity or change of quality of waters is in no case imposed as regards rights in non-navigable streams. The perpetuity and non-separable attachment of the common-law water right to riparian estates no longer obtain, with respect to the riparian water right of California.

University of Wisconsin, R. H. Hess. Madison, Wis. 